\title{
Essential Oil Composition of Alluaudia procera and in Vitro Biological Activity on Two Drug-Resistant Models
}

\author{
Paola Poma ${ }^{1}$, Manuela Labbozzetta ${ }^{1}$, Pietro Zito ${ }^{1}{ }^{(D}$, Rosa Alduina ${ }^{1}(\mathbb{D}$, \\ Aro Vonjy Ramarosandratana ${ }^{3}$, Maurizio Bruno ${ }^{1}$, Sergio Rosselli ${ }^{2, *} \mathbb{C}$, Maurizio Sajeva ${ }^{1, *}$ and \\ Monica Notarbartolo ${ }^{1, *}$ \\ 1 Department of Biological, Chemical and Pharmaceutical Science and Technology (STEBICEF), University of \\ Palermo, Viale delle Scienze, 90128 Palermo, Italy \\ 2 Department of Agricultural, Food and Forest Sciences, University of Palermo Viale delle Scienze, \\ 90128 Palermo, Italy \\ 3 Department of Plant Biology and Ecology, University of Antananarivo, PO Box 906, \\ Antananarivo 101, Madagascar \\ * Correspondence: sergio.rosselli@unipa.it (S.R.); maurizio.sajeva@unipa.it (M.S.); \\ monica.notarbartolo@unipa.it (M.N.)
}

Received: 24 June 2019; Accepted: 5 August 2019; Published: 7 August 2019

check for updates

\begin{abstract}
Drug resistance is a major obstacle in antibiotic and antitumor chemotherapy. In response to the necessity to find new therapeutic strategies, plant secondary metabolites including essential oils (EOs) may represent one of the best sources. EOs in plants act as constitutive defenses against biotic and abiotic stress, and they play an important role in the pharmacology for their low toxicity, good pharmacokinetic and multitarget activity. In this context, natural products such as EOs are one of the most important sources of drugs used in pharmaceutical therapeutics. The aim of this paper was to identify the chemical composition of the essential oil of Alluaudia procera leaves, obtained by hydrodistillation and analysed by gas chromatography-mass spectrometry, and to verify its biological activities on acute myeloid leukemia cancer cell HL60 and its multidrugresistant variant HL60R and the Gram-positive Staphylococcus aureus exhibiting multi-antibiotic resistance. We speculate that cytotoxic and antibiotic effects observed in the tested resistant models may be due to the coordinate activities of forty compounds detected or to the $\mathrm{C}_{16}$ macrocyclic lactones which are the major ones $(30 \%)$. Our data confirm the possibility of using EOs as therapeutic strategies in resistant models is due to the heterogeneous composition of the oils themselves.
\end{abstract}

Keywords: Didiereaceae; essential oil; acute myeloid leukemia cell; succulent plants

\section{Introduction}

Family Didiereaceae Drake includes six genera of xerophytic shrubs or small trees. The family is closely related to Cactaceae. The genus Alluaudia Drake is endemic to Southern Madagascar dry forest and composed of six species which are spiny trees usually 3 to $10 \mathrm{~m} \mathrm{[1].} \mathrm{Alluaudia} \mathrm{spp.}$ especially $A$. ascendens and $A$. procera are dominant trees in forest stands providing several ecosystem services. Abundant scientific literature reported their consumption by folivorous lemurs to supply protein and non-protein energy nutrient, fiber and water [2-4] but also their use as sleeping sites [5]. Alluaudia procera (Figure 1) is among extracted forest products used as fuel wood, making house and furniture $[6,7]$. 


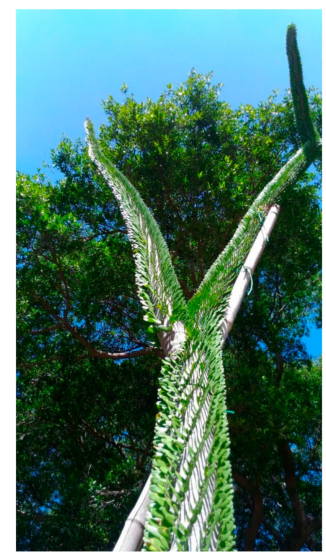

Figure 1. Alluaudia procera growing at the Botanical Garden of the University of Palermo.

A. procera has also some cultural value for local communities as the species is planted around burial sites to reinforce the taboos that protect them and also planted as a symbol of friendship or alliance [8]. Linholm et al. [9] investigated the cytotoxicity of a fractionated polypeptide fraction of Alluaudia humbertii which, among 100 species tested, showed a very low activity against human embryonal lung cells. Rasamoelisendra et al. [10] investigated the chemical composition of Alluaudia dumosa by methanol extraction. To the best of our knowledge, no data on the chemical composition of the essential oils (EOs) of the genus are available. The biological properties of EOs are widely documented from a vast literature that demonstrates in vitro anticancer, antibioceptive, antiviral, antiphlogistic and antimicrobial activity of these mixtures of volatile compounds [11,12]. This wide spectrum of biological activities is generally accompanied by biodegradability and reduced toxicity [12]. In plants, EOs act as constitutive defenses against biotic (e.g., herbivores and microorganisms) and abiotic (e.g., heath and light) stresses [13]. Succulent plants are adapted to dry environments where both environmental and biological stresses are high, and strong constitutive defenses are necessary to survive in their hostile habitat. For this reason, our team is investigating the EO composition of several species [14] of succulent plants to verify their possible useful biological activities against pathologies characterized by drug resistance. Multidrug resistance (MDR) is a major obstacle to successfully treating acute myeloid leukemia (AML) patients with chemotherapy. There is emerging evidence that the inability of the cells to undergo apoptosis contributes in several ways to the genesis and progression of cancer and may also represent a critical cause of tumor drug resistance. MDR is characterized by decreased intracellular drug accumulation after a period of drug administration, which is mediated by increase of drug efflux by ATP-binding cassette (ABC) transporters such as P-glycoprotein (P-gp) and multidrug resistance protein 1 (MRP1) [15-17]. Therefore, the search for novel anticancer drugs that are effective on multidrug resistant AML is in progress. In this context, natural products are one of the most important sources of drugs used in pharmaceutical therapeutics. Pharmacological resistance is represented also by the infectious drug resistant diseases. Microorganisms are present worldwide and the control of their growth and diffusion is of extreme importance in various environment, i.e., to combat infectious diseases in healthcare and in veterinary $[18,19]$, or in cultural heritages to reduce biodeterioration processes [20]. Mulani et al. [21] indicated different therapeutic strategies against six nosocomial pathogens (ESKAPE) that exhibit multidrug resistance and virulence: Enterococcus faecium, Staphylococcus aureus, Klebsiella pneumoniae, Acinetobacter baumannii, Pseudomonas aeruginosa and Enterobacter spp. Persistent use of antibiotics has provoked the emergence of MDR and extensively drug resistant (XDR) bacteria, which render even the most effective drugs ineffective. The development of novel therapeutics to treat drug resistant infections could be represented by alternative therapies such as use of antibiotics in combination or with adjuvants, bacteriophages, antimicrobial peptides, nanoparticles and photodynamic light therapy but also by use of EOs [22]. In this paper we identified and tested the in vitro biological activities of the EO of Alluaudia procera in HL60 leukemia cell line and 
its MDR variant HL60R and on Gram-negative Escherichia coli and the Gram-positive Staphylococcus aureus exhibiting antibiotic resistance.

\section{Results}

\subsection{Chemical Composition}

In the EO of $A$. procera leaves forty compounds, representing about the $96 \%$ of the oil, were identified: Thirteen aliphatic hydrocarbons $(9.3 \%)$, four oxygenated monoterpenes $(0.8 \%)$, two sesquiterpene hydrocarbons $(0.8 \%)$, two oxygenated sesquiterpenes $(1.3 \%)$, three diterpene hydrocarbons $(10.4 \%)$, one oxygenated diterpene $(8.0 \%)$, six $\mathrm{C}_{13}$ norisoprenoids $(5.4 \%)$ and seven macrolactones $(58.7 \%)$ as shown in Table 1 . The sample yielded $17.36 \mathrm{mg}(0.003 \%)$.

(Z)-Oxacycloheptadec-8-en-2-one (18.1\%) (Figure 2) with two $(15.2 \%$ and $10.8 \%)$ of its four isomers were the most abundant compounds, followed by trans-phytol $(8.0 \%)$, the third ambrettolide isomer $(7.4 \%)$, neophytadiene (5.6\%), the fourth ambrettolide isomer (3.8\%) and vitispirane (3.7\%).

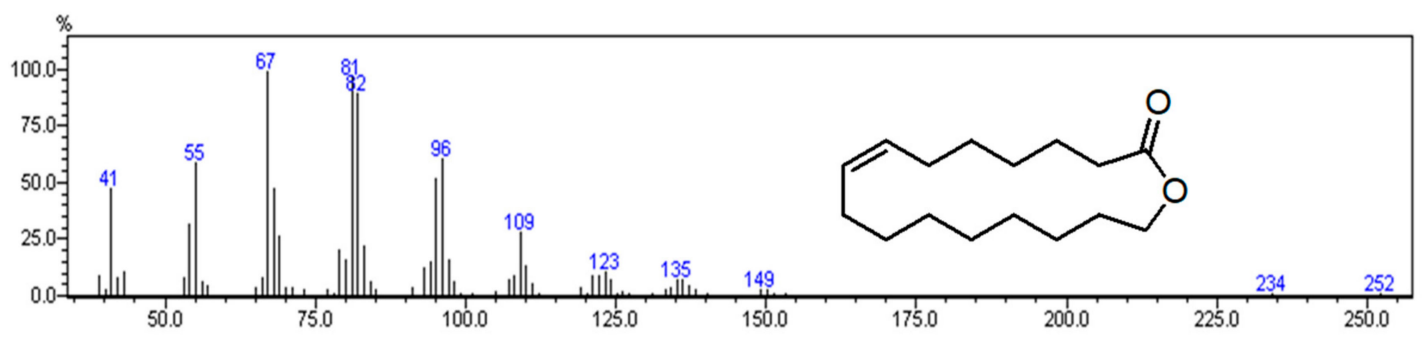

Figure 2. Mass spectrum and chemical structure of (Z)-Oxacycloheptadec-8-en-2-one (LRI 1914-2385) found in the present study.

(Z)-Oxacycloheptadec-8-en-2-one is reported in the literature with several names and we report here those found in NIST [23]: Ambrettolid; Ambrettolide; Musk ambrette; Musk ambrette natural; Musk natural; Natural musk ambrette; Oxacycloheptadec-8-en-2-one, (Z)-; (Z)-7-Hexadecen-16-olide; 16-Hydroxy-7-hexadecenoic acid lactone, cis-; Oxacycloheptadec-8-en-2-one, (8Z)-; hexadec-7-en-16-olide. For a matter of simplicity, we will use the synonym ambrettolide through the text.

\subsection{In Vitro Anticancer Activity}

The characteristics of the acute myeloid leukemia cell line HL60 and of its doxorubicin-resistant and MDR variant HL60R have been described previously [15]. Resistance of HL60R cell line were evaluated after two exposition steps to doxorubicin ( $250 \mathrm{ng}$ in $8 \mathrm{~mL}$ of RPMI) by the trypan blue dye exclusion test. The cytotoxicity of $A$. procera $\mathrm{EO}$ in cancer cells has never been investigated. Under our experimental conditions, the EO induced a concentration-dependent reduction of cancer cell viability (Figure 3A,B) of HL60 and HL60R cells after $72 \mathrm{~h}$ of treatment. The concentration of essential oil that decreased cell viability to $50 \%\left(\mathrm{IC}_{50}\right.$ ) was $25.5 \pm 5.5 \mu \mathrm{g} / \mathrm{mL}$ and $45.8 \pm 6.2 \mu \mathrm{g} / \mathrm{mL}$ respectively. We co-treated same cell lines with EO in combination with doxorubicin, a conventional antiblastic drug often used as a first line treatment in the leukemia. As can be deduced from the data reported in Table 2, the expected percentage of cell viability is similar to that observed. These results indicate that the combination of $\mathrm{EO}$ and doxorubicin determines only an additive effect. 
Table 1. Chemical composition of A. procera essential oil.

\begin{tabular}{|c|c|c|c|c|c|}
\hline LRI $^{a}$ & LRI $^{b}$ & Compound & $\%$ & $\mathrm{Id}^{\mathrm{c}}$ & Class $^{d}$ \\
\hline 1069 & 1435 & cis-Linalool oxide & 0.2 & 1,2 & $\mathrm{OM}$ \\
\hline 1085 & 1436 & trans-Linalool oxide & 0.1 & 1,2 & $\mathrm{OM}$ \\
\hline 1099 & 1551 & Linalool & 0.2 & $1,2,3$ & $\mathrm{OM}$ \\
\hline 1186 & 1693 & $\alpha$-Terpineol & 0.3 & $1,2,3$ & $\mathrm{OM}$ \\
\hline 1253 & 1463 & cis-Edulan & 0.3 & 1,2 & $\mathrm{C} 13$ \\
\hline 1272 & 1508 & Vitispirane (isomer not identified) & 3.7 & 1,2 & $\mathrm{C} 13$ \\
\hline 1309 & 1595 & trans-Edulan & 0.9 & 1,2 & $\mathrm{C} 13$ \\
\hline 1345 & 1734 & 1,1,6-Trimethyl-1,2-dihydronaphthalene & 0.2 & 1,2 & $\mathrm{C} 13$ \\
\hline 1380 & 1807 & trans- $\beta$-Damascenone & 0.1 & 1,2 & $\mathrm{C} 13$ \\
\hline 1383 & 1804 & 1,4,6-trimethyl-1,2-dihydronaphthalene & 0.2 & 1,2 & $\mathrm{C} 13$ \\
\hline 1411 & 1569 & cis- $\alpha$-Bergamotene & 0.5 & 1,2 & $\mathrm{SH}$ \\
\hline 1508 & 1735 & $(E, E)$ - $\alpha$-Farnesene & 0.3 & 1,2 & $\mathrm{SH}$ \\
\hline 1634 & 2032 & 1-epi-Cubenol & 0.3 & 1,2 & OS \\
\hline 1700 & 1700 & Heptadecane & 0.2 & $1,2,3$ & $\mathrm{H}$ \\
\hline 1738 & 2492 & $\gamma$-Costol & 1.0 & 1,2 & OS \\
\hline 1756 & 2606 & Benzyl benzoate & 0.5 & $1,2,3$ & $\mathrm{O}$ \\
\hline 1800 & 1800 & Octadecane & 0.4 & $1,2,3$ & $\mathrm{H}$ \\
\hline 1838 & 1926 & Neophytadiene (isomer not identified) & 5.6 & 1,2 & $\mathrm{DH}$ \\
\hline 1863 & 1955 & Neophytadiene (isomer not identified) & 1.1 & 1,2 & $\mathrm{DH}$ \\
\hline 1880 & 1982 & Neophytadiene (isomer not identified) & 3.7 & 1,2 & $\mathrm{DH}$ \\
\hline 1900 & 1900 & Nonadecane & 0.9 & $1,2,3$ & $\mathrm{H}$ \\
\hline 1906 & 2418 & Ambrettolide isomer & 7.4 & 1,2 & ML \\
\hline 1914 & 2385 & Ambrettolide [(Z)-Oxacycloheptadec-8-en-2-one] & 18.1 & $1,2,3$ & ML \\
\hline 1919 & 2414 & Ambrettolide isomer & 15.2 & 1,2 & ML \\
\hline 1924 & 2373 & Ambrettolide isomer & 10.8 & 1,2 & ML \\
\hline 1928 & 2393 & Ambrettolide isomer & 3.8 & 1,2 & ML \\
\hline 2000 & 2000 & Eicosane & 0.5 & $1,2,3$ & $\mathrm{H}$ \\
\hline 2100 & 2100 & Heneicosane & 0.6 & $1,2,3$ & $\mathrm{H}$ \\
\hline 2111 & 2614 & trans-Phytol & 8.0 & $1,2,3$ & OD \\
\hline 2114 & 2586 & 14-Methyl-8-hexadecyn-1-ol & 1.2 & 1,2 & $\mathrm{O}$ \\
\hline 2119 & 2575 & Oxacyclononadec-10-en-2-one (isomer not identified) & 1.3 & 1,2 & ML \\
\hline 2128 & 2610 & Oxacyclononadec-10-en-2-one (isomer not identified) & 2.1 & 1,2 & ML \\
\hline 2200 & 2200 & Docosane & 0.3 & $1,2,3$ & $\mathrm{H}$ \\
\hline 2300 & 2300 & Tricosane & 0.4 & $1,2,3$ & $\mathrm{H}$ \\
\hline
\end{tabular}


Table 1. Cont

\begin{tabular}{cccccc}
\hline $\mathbf{L R I}^{\mathbf{a}}$ & $\mathbf{L R I}^{\mathbf{b}}$ & Compound & $\mathbf{\%}$ & $\mathbf{I d}^{\mathbf{c}}$ & Class $^{\mathbf{d}}$ \\
\hline 2400 & 2400 & Tetracosane & 0.1 & $1,2,3$ & $\mathrm{H}$ \\
2500 & 2500 & Pentacosane & 0.8 & $1,2,3$ & $\mathrm{H}$ \\
2600 & 2600 & Hexacosane & 0.5 & $1,2,3$ & $\mathrm{H}$ \\
2700 & 2700 & Heptacosane & 3.1 & $1,2,3$ & $\mathrm{H}$ \\
2800 & 2800 & Octacosane & 0.4 & $1,2,3$ & $\mathrm{H}$ \\
2900 & 2900 & Nonacosane & 1.1 & $1,2,3$ & $\mathrm{H}$ \\
\hline
\end{tabular}

Class of Compounds

Oxygenated Monoterpene

Sesquiterpene Hydrocarbons $\quad 0.8$

1.8

Diterpene Hydrocarbons $\quad 10.4$

Oxygenated Diterpene $\quad 8.0$

Aliphatic Hydrocarbons $\quad 9.3$

$\mathrm{C}_{13}$ Norisoprenoids $\quad 5.4$

Macrolactones $\quad 58.7$

Others

Total 96.4

${ }^{a}$ Linear Retention Index on a HP-5 MS column; ${ }^{\mathrm{b}}$ linear Retention Index on a Supelcowax 10 column; ${ }^{\mathrm{c}}$ 1: retention index; 2: MS, mass spectrum; 3: co-injection with authentic compound;

d OM: oxygenated monoterpenes, $\mathrm{SH}$ : sesquiterpene hydrocarbons, OS: oxygenated sesquiterpenes, DH: diterpene hydrocarbons, $\mathrm{H}$ : hydrocarbons, $\mathrm{C}_{13}$ : $\mathrm{C}_{13}$ norisoprenoids, ML:

macrolactones, O: others. 
A

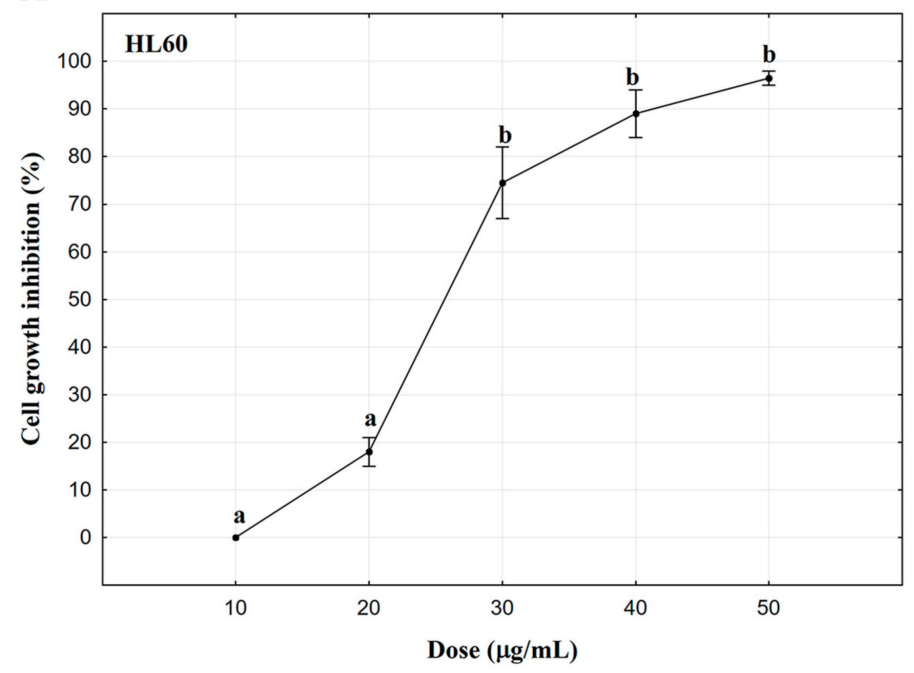

B

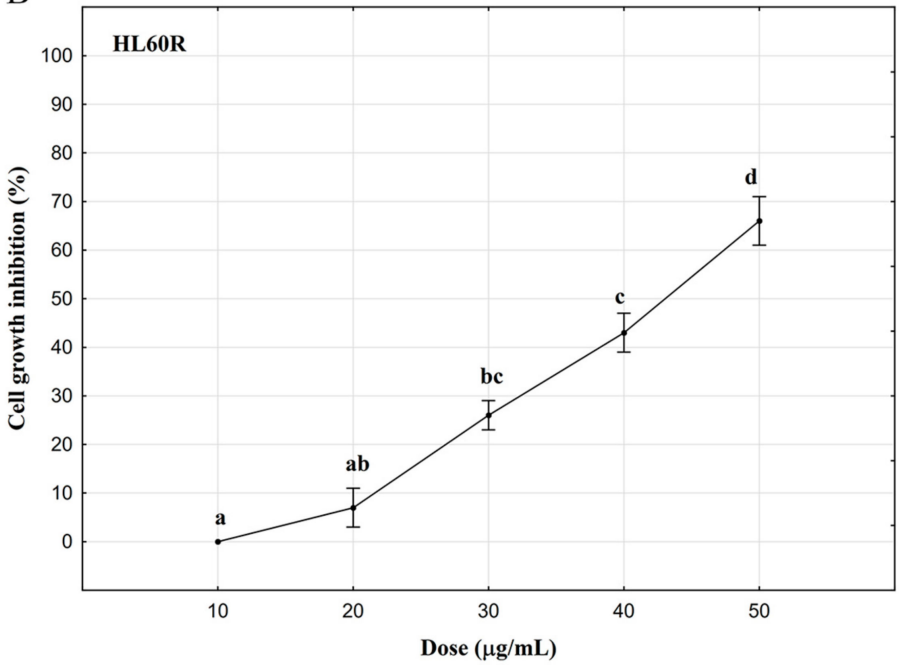

Figure 3. Cytotoxic activity of A. procera essential oil on HL60 (A) and HL60 R (B) cell lines. Cell viability was assessed by MTS. Data are expressed as mean \pm standard error (SE) of at least three different experiments performed in triplicate. Different letters represent significant differences in cytotoxic activity among the concentrations of each cell line (Tukey test, $p<0.05$ ).

Table 2. Cell growth inhibition in HL60 and its multidrug resistant variant HL60R following treatment with essential oil of $A$. procera and doxorubicin (Doxo) or a combination of these.

\begin{tabular}{|c|c|c|}
\hline Cell Lines and Treatments & Cell Viability (\%) & Expected $(\%)$ \\
\hline \multicolumn{3}{|l|}{ HL60 } \\
\hline Essential oil of $A$. procera $10 \mu \mathrm{g} / \mathrm{mL}$ & $100.0 \pm 0.0$ & \\
\hline Essential oil of $A$. procera $20 \mu \mathrm{g} / \mathrm{mL}$ & $82.0 \pm 2.1$ & \\
\hline Doxo $1 \mathrm{ng} / \mathrm{mL}$ & $90.0 \pm 0.7$ & \\
\hline Doxo $2 \mathrm{ng} / \mathrm{mL}$ & $84.5 \pm 3.9$ & \\
\hline Essential oil of A. procera $10 \mu \mathrm{g} / \mathrm{mL}+$ Doxo $1 \mathrm{ng} / \mathrm{mL}$ & $100.0 \pm 0.5$ & $90.0 \pm 0.7$ \\
\hline Essential oil of A. procera $10 \mu \mathrm{g} / \mathrm{mL}+$ Doxo $2 \mathrm{ng} / \mathrm{mL}$ & $93.0 \pm 3.1$ & $84.5 \pm 3.9$ \\
\hline Essential oil of A. procera $20 \mu \mathrm{g} / \mathrm{mL}+$ Doxo $1 \mathrm{ng} / \mathrm{mL}$ & $80.0 \pm 1.7$ & $74.0 \pm 1.4$ \\
\hline $\begin{array}{c}\text { Essential oil of A. procera } 20 \mu \mathrm{g} / \mathrm{mL}+\text { Doxo } 2 \mathrm{ng} / \mathrm{mL} \\
\text { HL60R }\end{array}$ & $71.0 \pm 2.2$ & $69.0 \pm 1.4$ \\
\hline Essential oil of $A$. procera $10 \mu \mathrm{g} / \mathrm{mL}$ & $100.0 \pm 0.0$ & \\
\hline Essential oil of A. procera $20 \mu \mathrm{g} / \mathrm{mL}$ & $70.5 \pm 3.2$ & \\
\hline Doxo $100 \mathrm{ng} / \mathrm{mL}$ & $87.5 \pm 3.9$ & \\
\hline Doxo 500 ng/mL & $76.5 \pm 4.6$ & \\
\hline
\end{tabular}


Table 2. Cont.

\begin{tabular}{ccc}
\hline Cell Lines and Treatments & Cell Viability (\%) & Expected (\%) \\
\hline Essential oil of A. procera $10 \mu \mathrm{g} / \mathrm{mL}+$ Doxo $100 \mathrm{ng} / \mathrm{mL}$ & $95.0 \pm 2.2$ & $87.5 \pm 3.9$ \\
Essential oil of A. procera $10 \mu \mathrm{g} / \mathrm{mL}+$ Doxo $500 \mathrm{ng} / \mathrm{mL}$ & $88.0 \pm 3.8$ & $76.5 \pm 4.6$ \\
Essential oil of A. procera $20 \mu \mathrm{g} / \mathrm{mL}+$ Doxo $100 \mathrm{ng} / \mathrm{mL}$ & $70.0 \pm 1.9$ & $62.0 \pm 5.6$ \\
Essential oil of A. procera $20 \mu \mathrm{g} / \mathrm{mL}+$ Doxo $500 \mathrm{ng} / \mathrm{mL}$ & $61.0 \pm 5.9$ & $54.0 \pm 5.6$ \\
\hline
\end{tabular}

Data are expressed as the mean \pm standard error of three independent experiments. There are not statistical differences among expected (\%) and cell viability (\%). Expected value: Sum of the effects of the agents alone minus that of the untreated cells.

\subsection{In Vitro Antibacterial Activity}

The antibacterial activity of the EO was evaluated against the Gram-negative E. coli K12 and the Gram-positive S. aureus ATCC25923 by disc diffusion antibiotic sensitivity assays. The growth of the Gram-positive strain S. aureus was inhibited in the presence of $20 \mu \mathrm{L}$ of EO at the concentration of $2 \mathrm{mg} / \mathrm{mL}$, while the growth of E. coli was not (Figure 4).

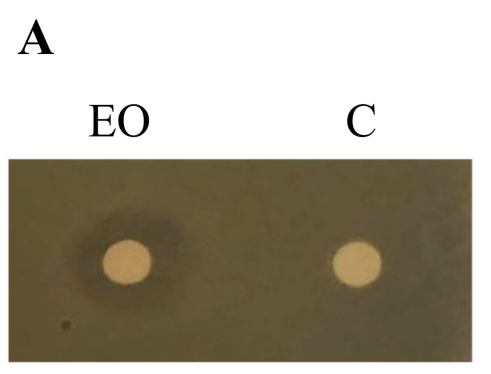

\section{B}

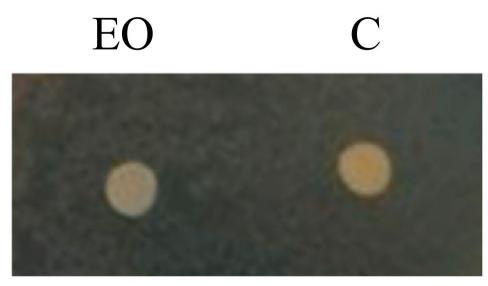

Figure 4. Antibacterial activity of the essential oil (EO) against S. aureus ATCC25923 (A) and E. coli K12 (B). The presence of the halo around the disk, previously soaked with the EO, demonstrates the antibacterial activity against S. aureus ATCC25923. C: Negative control.

Increasing concentrations of EO were added to S. aureus ATCC25923 cultures to determine the minimal inhibitory concentration (MIC) by broth microdilution method. Evaluation of total bacterial count showed that the MIC of EO is $10 \mu \mathrm{g} / \mathrm{mL}$, indeed the OD600 measurements were close to zero (Figure 5A). Thus, we plated a $100 \mu \mathrm{L}$ aliquot of the bacterial suspension from the control well, and the well containing 10 and $20 \mu \mathrm{g} / \mathrm{mL}$ of EO onto the non-selective growth solid medium. The evaluation of vital bacterial cells showed that only 6 colonies grew in presence of $10 \mu \mathrm{g} / \mathrm{mL}$ EO (Figure 5B) and no colonies in presence of $20 \mu \mathrm{g} / \mathrm{mL}$ (data not shown). This latter result demonstrated that EO does not only inhibit bacterial growth but has a bactericidal effect and revealed that $20 \mu \mathrm{g} / \mathrm{mL}$ correspond to the minimal bactericidal concentration (MBC) (Figure 5B).

The addition of $25 \mu \mathrm{g} / \mathrm{mL}$ of EO inhibited the growth of two MDR clinical isolates (S. aureus strain 5 and 11) which are resistant to penicillin, erythromycin, oxacillin, cephalosporins and amoxicillin-clavulanic acid. (Figure 6).

The comparison of the antibacterial activity of EO, erythromycin (Ery) and the combination of EO+Ery against the MDR S. aureus isolate 11 indicated that when erythromycin was used in combination with EO the effect was due to EO only (Table 3).

Table 3. Results of the disc diffusion antibiotic sensitivity assays. The diameter of the inhibition halos around the disk, previously soaked with EO and EO+Ery, is reported.

\begin{tabular}{cc}
\hline Incubation of Bacteria in Presence of & Diameter $(\mathbf{c m})$ of the Inhibition Halo \\
\hline EO & $0.8 \pm 0.05$ \\
EO + Ery & $0.8 \pm 0.03$ \\
Ery & $0 \pm 0.01$ \\
\hline
\end{tabular}


A

$\mathrm{EO} \mu \mathrm{g} / \mathrm{mL}$

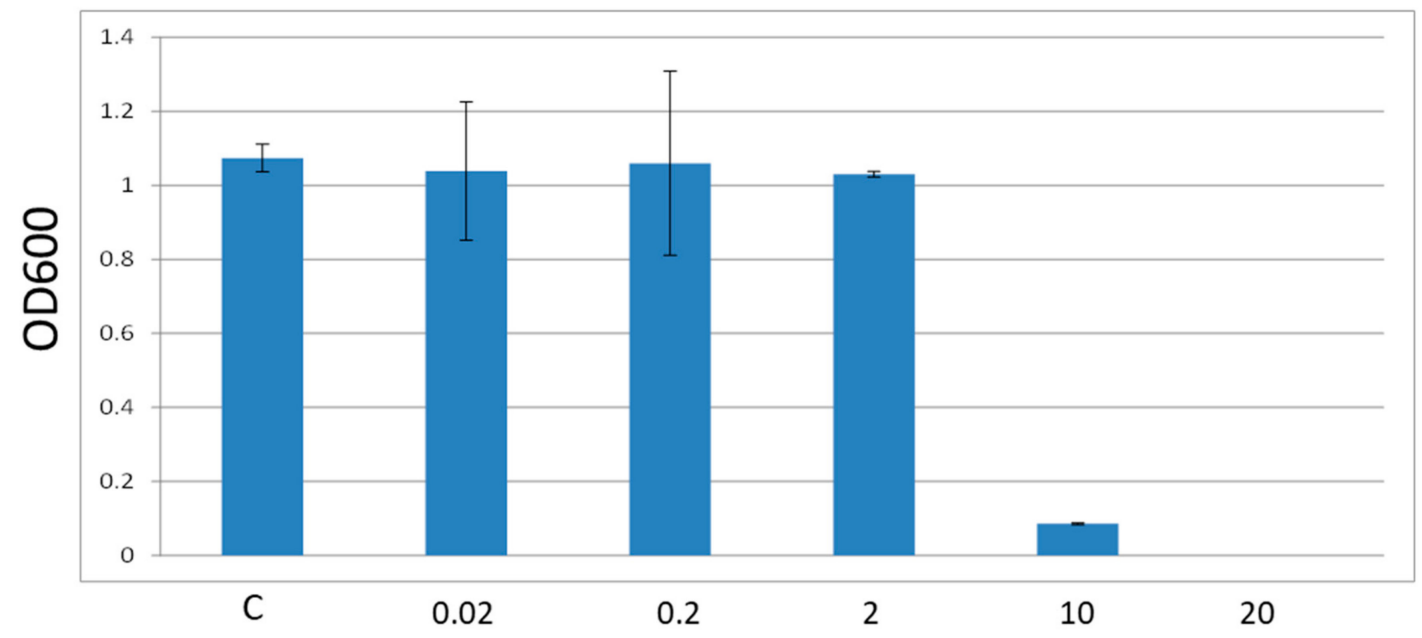

B
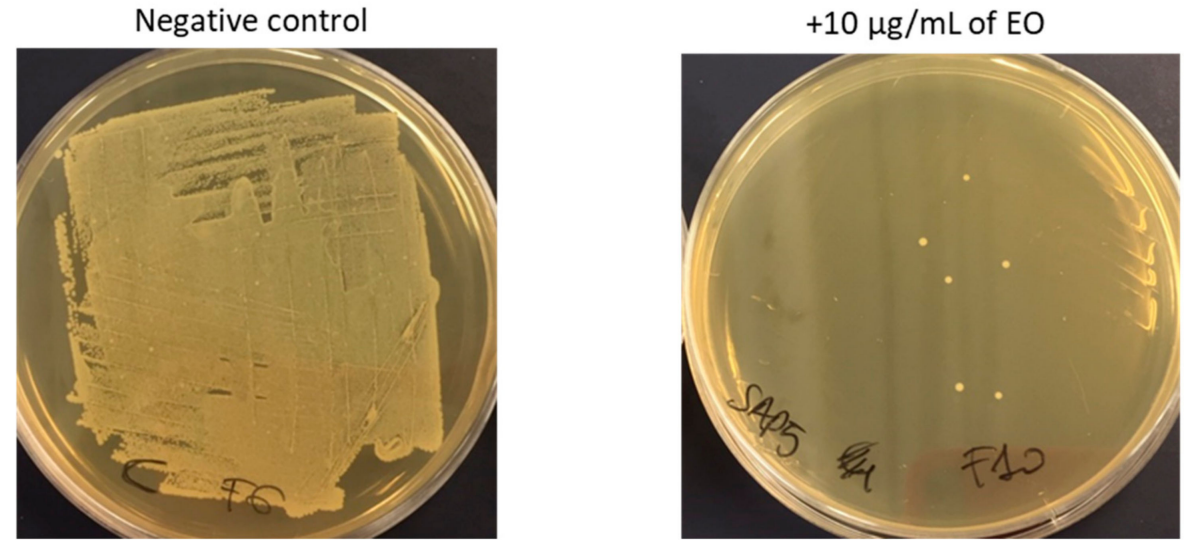

Figure 5. Effect of EO on S. aureus ATCC25923 growth. A: determination of total bacterial count. Data are average from triplicate experiments. Bars represent standard deviations of triplicate incubations. B: determination of vital bacterial count when $10 \mu \mathrm{g} / \mathrm{mL}$ of EO were added. Negative control represents the bacterial culture incubated with DMSO.
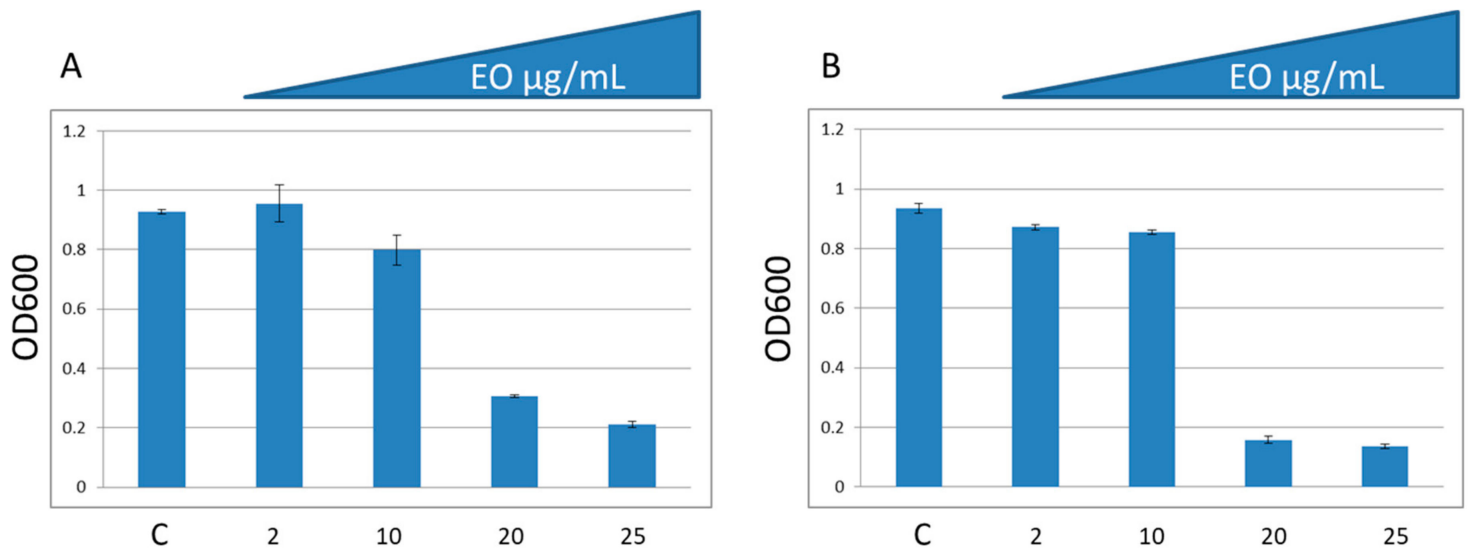

Figure 6. Effect of EO on growth of two MDR $S$. aureus isolates $(\mathbf{A}-$ S. aureus strain $11 ; \mathbf{B}-S$. aureus strain 5). Data are average from triplicate experiments. Bars represent standard deviations of triplicate incubations. 


\section{Discussion}

The aim of this paper was to identify the chemical composition of the EO of $A$. procera leaves and to verify its biological activity in two acute myeloid leukemia cell lines and against two microorganisms, E. coli and S. aureus. The chemical composition of the EO is quite peculiar. It includes higher terpenes (i.e., diterpenes), whereas mono and sesquiterpene are almost absent. Phytol, neophytadiene and its isomers constitute the terpenic fraction of the oil. The occurrence of $\mathrm{C}_{13}$ norisoprenoids is very common in plants. In fact, edulans, vitispirane, trimethyl-dihydronaphthalenes, very flavouring volatile substances, are often found together contributing to the overall fruit flavour; also, trans- $\beta$-damascenone is one of the most potent of all known wine flavor compounds. All of them $\left(\mathrm{C}_{13}\right.$ norisoprenoids $)$ derive from different carotenoid degradation pathways, and this fact confirms the plants' disposition towards diterpenes biosynthesis. They, besides having several biological effects, contribute to constitutive defenses of the plant [24]. Interestingly, the major constituents of essential oil are five $C_{16}$ macrocyclic lactones that together constitute $58.7 \%$ of the EO composition. Ambrettolide [(Z)-oxacycloheptadec-8-en-2-one] is the major component $(18.1 \%)$ along with four isomers, similarly to Leffingwell et al. [25] in Latakia tobacco volatiles. Ambrettolide is a valuable flavor material isolated from ambrette (Abelmoschus moschatus Medicus = Hibiscus abelmoschus L.) seeds where it is the second most abundant compound $(13 \%)$ [26]. This compound is rare among plants [27], and it has been found, $0.7 \%$ to $1.9 \%$, in the headspace of the flowers of two tropical orchids [28] and in the essential oil $(0.8 \%)$ of the flowers of Trollius europaeus (Ranunculaceae) [27].

The GC-MS analysis of $A$. procera EO showed the presence of five main peaks identified by the libraries as ambrettolide with a similarity ranging from $90 \%$ to $96 \%$. A comparison with the linear retention indices (LRI) reported in literature allowed us to identify the major of these peaks as ambrettolide. Ambrettolide (LRI 1914 - 2385) was verified by authentic standard as reported in Materials and Methods. The remaining were attributed to positional and/or configurational isomers of the double bond that could arise biogenetically or by isolation procedure (hydrodistillation and thermal isomerization).

Other two compounds, eluting after the ambrettolide and their isomers, have been matched as ambrettolide by the libraries. As reported by other authors $[29,30]$ for the oils of Hibiscus abelmoschus (= Abelmoschus moschatus), another macrolide homologue of ambrettolide has been identified as oxacyclononadec-10-en-2-one. It has been reported by Leffingwell et al. [25] also. On the basis of these findings, we have assigned the structures of oxacyclononadec-10-en-2-one to one of these two compounds occurring in A. procera leaves $\mathrm{EO}$ and its isomeric form to the other one, similarly as for the ambrettolide, comparing the LRI reported in literature. Their MS spectra [30] are very similar to ambrettolide, and this can explain the mismatched identification by the libraries. The analysis of $A$. procera leaves EO showed that it is mainly (58.7\%) composed by macrolactones (macrolides) conferring to it powerful biological activity. The presence of a high percentage of macrolides may contribute to the constitutive defense of $A$. procera leaves against possible microorganism attack.

The presence of macrolides in Alluaudia may probably contribute to the defense against microorganisms preventing rooting of the leaves. The pharmacological profile of $A$. procera EO is very interesting probably because of the high percentage content of macrolide compounds. Macrolides contain macrocyclic lactone ring and constitute a wide family of natural products, many of which present antibiotic activity. The non-antibiotics macrolide drugs like tacrolimus, everolimus and sirolimus are immunosuppressants, used in transplant rejection and in the treatment of some autoimmune diseases, while everolimus and sirolimus are used as immunosuppressants and antitumor drugs [31]. Despite having different pharmacological activities, macrolide compounds are substrate of P-gp [32], in particular the antitumor effects of everolimus and sirolimus are well documented as inhibitors of cellular proliferation through mTOR (mammalian target of rapamycin) inhibition in some tumor models such as renal cell carcinoma, hepatocellular carcinoma and breast cancer [33,34]. For all these reasons, we investigated both the antitumor and antimicrobial activities of $A$. procera $\mathrm{EO}$ in two resistant models. We compared the biological effect of EO in the acute myeloid leukemia cell line HL60 with its 
MDR variant HL60R that in contrast to their parental cells lacked sensitivity to cell death induction from diverse stimuli, including doxorubicin and cisplatin administration [35]. Drug resistance in HL60R variant cells is characterized by overexpression of a variety of proteins, which belong to the P-gp but also by constitutive expression of inhibitor of apoptosis proteins (IAPs), family members proteins that we previously described play an important role in tumor cell resistance to drug induced apoptosis and show also a different expression in drug-resistant and -sensitive HL60 leukemia cells [35,36]. Consistent with the biological role of IAPs, it has been reported that they may adversely affect the prognosis of patients with solid tumors or acute myeloid leukemia [37,38]. Screening of several natural products in the search for novel anticancer agents against human leukemia HL60 and its multidrug resistant variant HL60R cells led us to identify antitumor activity in the EO from A. procera leaves. The different cytotoxic level of EO between HL60 and HL60R, like doxorubicin, could indicate that $\mathrm{C}_{16}$ macrocyclic lactones could be substrate of P-gp. Since the antitumor drug doxorubicin still today is the first-choice treatment for AML in combination with cytarabine and/or etoposide [38], there is an urgent need to explore alternative therapeutic approaches to improve outcomes. In our cellular model, which consist of a cell line doxorubicin resistant, we carried out cytotoxicity assay using a combination of essential oil of A. procera and doxorubucin. As this combination causes only an additive cytotoxic effect, we suppose that essential oil or its major compounds are substrate of P-gp, as indeed many macrolides are. It is known that doxorubicin administered in increasing doses is able to enhance the transcription of the gene that encodes for P-gp via NF-kB, making the cells resistant to chemotherapy [35]. The mechanism of action of the $\mathrm{C}_{16}$ macrocyclic lactones found in the present study is unknown, but on the basis of our results, we think that they could exert an antiproliferative effect by inhibiting mTOR and/or NF- $k B$ like structural analogues, substrate of P-gp used as anticancer agents. The presence of $\mathrm{C}_{16}$ macrocyclic lactones also led us to verify the potential effect on resistant bacteria. In the last years, the appearance of multidrug-resistant microorganisms has increased. Therefore, there is the urgent necessity to find new, safe, efficient and economical compounds [39-41] for fighting the spread of multidrug resistant bacteria, especially in healthcare.

Our results show that the EO is active against $S$. aureus. Interestingly the EO was active also against the MDR clinical isolates tested, which are resistant to penicillin, erythromycin, oxacillin, cephalosporins and amoxicillin-clavulanic acid. The clinical isolates were characterized by the coordinate expression of some genes that encode for endotoxins and mecA gene expression (methicillin resistant), which confer an aggressive phenotype [42,43]. Our results show that EO exerts a bacteriostatic and bactericidal effects against $S$. aureus, unlike macrolide antibiotic compounds which are bactericidal only at high doses. We surmise that EO works inside the Gram-positive cells thanks to its lipophilic properties. The EO showed no effect against $E$. coli since the protection due to the LPS layer could prevent its entry. It is interesting to note that when supplying EO in combination with erythromycin the antimicrobial effect is due to the EO only.

The chemical composition of oil derived from the seeds of Abelmoschus moschatus L. (Malvaceae), named ambrette seed oil, showed ambrettolide as the second major compound [26]. In this paper, the authors suggested that the antimicrobial effect of ambrette seed oil may be due to damages in the cell membranes because of its hydrophobicity [26]. The authors stated that the Gram-positive bacteria are more sensitive to essential oils than Gram-negative bacteria because of the higher charged outer membrane.

Our data indicate that A. procera EO induced cytotoxic effect in the cell lines investigated and also as antimicrobial against the $S$. aureus isolates. Both models show MDR and the efficacy of EO may be further tested to verify possible pharmacological applications. Further studies are necessary to verify if the biological activities described are due to the major compounds, namely ambrettolide, or to a combination of the identified compounds. In conclusion, although this is a new and emerging area of cancer research, the ability of EOs and their components to have such diverse antiproliferative activities through acting on various pathways and cellular mechanisms is engaging. Moreover, the possibility of using essential oils as therapeutic strategies in resistant models is due to the heterogeneous composition 
of the oils themselves; for this reason, the propensity to develop drug resistance is unlikely different from what happens when using conventional drugs consisting of a single molecule.

\section{Materials and Methods}

\subsection{Plant Species}

Alluaudia procera Drake is a small tree branching from near the base with spiral rows of spines [44,45]. At the start of every growing season leaves are produced in pairs above the spines and fall during the dry season [1]. A. procera is listed in CITES Appendix II together with the whole family Didiereaceae. Its seeds are exempt from the provisions of CITES. The IUCN red list reports this species as near threatened [46].

\subsection{Plant Material}

Leaves of Alluaudia procera were collected in July 2018 from plants cultivated at the Botanical Garden of the University of Palermo. The plants were raised from seeds in 1984 and cultivated in the open with reference code: Didiereaceae 4 . The seeds were obtained and the plants raised before the Convention on Biological Diversity (CBD) entered into force on 29 December 1993 and therefore are pre-CBD specimens. The matrices were placed in paper bags and kept at $-30{ }^{\circ} \mathrm{C}$ for $24 \mathrm{~h}$ before hydrodistillation. No specific permits were required for the described location and for the collection of plant material because the plants are part of the living collection of the Botanical Garden of the University of Palermo and the authors have access to that.

\subsection{Essential Oil Isolation and Chemical Characterization}

The matrices A. procera (600 g-about 1700 leaves) were hand cut in small pieces and hydrodistillated for $3 \mathrm{~h}$ in a Clevenger-type apparatus, using n-pentane as collection solvent [47]. The oil was dried by anhydrous sodium sulphate and stored at $-30{ }^{\circ} \mathrm{C}$ until chemical analysis and pharmacological tests. To prepare the stock solution for biological studies $2 \mathrm{mg}$ of essential oil were dissolved in $1 \mathrm{~mL}$ of dimethyl sulfoxide (DMSO). The GC analysis was performed in an Agilent 7000C GC system (Agilent, Santa Clara, CA, USA), fitted with a fused silica Agilent HP-5MS capillary column ( $30 \mathrm{~m} \times 0.25 \mathrm{~mm}$ i.d.; $0.25 \mu \mathrm{m}$ film thickness, ), coupled to an Agilent triple quadrupole Mass Selective Detector MSD 5973; ionization voltage $70 \mathrm{eV}$; electron multiplier energy $2000 \mathrm{~V}$; transfer line temperature, $295^{\circ} \mathrm{C}$. Helium was the carrier gas $\left(1 \mathrm{~mL} \mathrm{~min}^{-1}\right)$. The other $\mathrm{GC}$ analysis was performed in a Shimadzu QP 2010 plus (Shimadzu, Kyoto, Japan), single quadrupole GC/MS system, fitted with a Supelcowax 10 capillary column $(30 \mathrm{~m} \times 0.25 \mathrm{~mm}$ i.d.; $0.25 \mu \mathrm{m}$ film thickness, (Merck KGaA, Darmstadt, Germany); ionization voltage $70 \mathrm{eV}$; transfer line temperature, $280^{\circ} \mathrm{C}$. Helium was the carrier gas $\left(1 \mathrm{~mL} \mathrm{~min}^{-1}\right)$. For both columns, the temperature was initially kept at $40^{\circ} \mathrm{C}$ for $5 \mathrm{~min}$, then gradually increased to $250{ }^{\circ} \mathrm{C}$ at $2{ }^{\circ} \mathrm{C} \mathrm{min}-1$ rate, held for $15 \mathrm{~min}$ and finally raised to $270{ }^{\circ} \mathrm{C}$ at $10^{\circ} \mathrm{C}$ $\mathrm{min}^{-1}$. One $\mu \mathrm{L}$ of diluted samples $\left(1 / 100 v / v\right.$, in $n$-pentane) was injected at $250{ }^{\circ} \mathrm{C}$ automatically and in the splitless mode; transfer line temperature, $295^{\circ} \mathrm{C}$.

\subsection{Identification of Compounds}

Identification of compounds was carried out using NIST 11, Wiley 9, FFNSC 2, and Adams [48] databases. These identifications were confirmed by Linear Retention Indices (LRI) with those available in literature by SciFinder database. Some of the compounds were also confirmed by comparison of mass spectra and retention times with standard compounds available in laboratory. (Z)-Oxacycloheptadec-8-en-2-one authentic standard (100 $\mu \mathrm{g} / \mathrm{mL}$ in cyclohexane), product code DRE-XA15756500CY, was purchased by LGC DR Ehrenstorfer ${ }^{\mathrm{TM}}$. The retention indices were determined in relation to a homologous series of $n$-alkanes $\left(C_{8}-C_{30}\right)$ injected under the same operating conditions. Component relative (\%) amounts were calculated based on GC peak areas without using correction factors. 


\subsection{Cell Culture}

The HL60 cells were obtained from ATCC ${ }^{\circledR}$ (CCL-240, Rockville, MD, USA), while its variant HL60R, was selected for multidrug resistance (MDR) by exposure to gradually increasing concentrations of doxorubicin. One milliliter of cell suspension was distributed into each well of 24-well culture plates and $24 \mathrm{~h}$ later doxorubicin was added. After $24 \mathrm{~h}$ cell viability was determined by the ability of cells to exclude trypan blue dye and expressed as percent of control cell growth. The cells were routinely maintained in RPMI-1640 (HyClone Europe Ltd., Cramlington, UK) supplemented with $10 \%$ heat-inactivated fetal calf serum, $1 \%$ L-glutamine, $1 \%$ penicillin/streptomycin solution (all from HyClone Europe). The cells were grown in a humidified atmosphere at $37^{\circ} \mathrm{C}$ in $5 \% \mathrm{CO}_{2}$. Cells having a narrow range of passage number were used for all experiments. The cultured were routinely tested for Mycoplasma infection.

\subsection{Cytotoxicity Assay}

Exponentially growing cells were suspended at $5 \times 10^{4}$ cells $/ \mathrm{mL}$ in complete medium, and $200 \mu \mathrm{L}$ of cell suspension were distributed into each well of 96 -well microtiter plates and incubated overnight at $37^{\circ} \mathrm{C}$. At time 0 , the medium was replaced with fresh complete medium supplemented of essential oil at the indicated concentrations. Following $72 \mathrm{~h}$ of treatment, $16 \mu \mathrm{L}$ of a commercial solution (obtained from Promega Corporation Madison, WI, USA) containing 3-(4,5-dimethylthiazol-2-yl)-5-(3-carboxymethoxyphenyl)-2-(4-sulphophenyl)-2H-tetrazolium (MTS) and phenazine ethosulfate were added. The plates were incubated for $4 \mathrm{~h}$ in a humidified atmosphere at $37^{\circ} \mathrm{C}$ in $5 \% \mathrm{CO}_{2}$. The bioreduction of the MTS dye was assessed by measuring the absorbance of each well at $490 \mathrm{~nm}$. Cytotoxicity was expressed as a percentage (mean $\pm \mathrm{SE}$ ) of the absorbance measured in the control cells.

\subsection{Microorganisms}

Two reference strains, Staphylococcus aureus ATCC25923 and Escherichia coli K12, and two toxigenic and multidrug resistant (MDR) S. aureus strains 11 and 5 isolated from clinical environments [42] were used in this study and were maintained as described elsewhere [43].

\subsection{Determination of the Antibacterial Activity}

The antibacterial activity was assessed against the reference strains, S. aureus ATCC25923 and E. coli K12, by using a disc diffusion antibiotic sensitivity assays as described in literature $[49,50]$. In brief, a dense suspension ( $\sim 10^{7}$ cells) of each microorganism was spread onto the Luria Bertani agar medium (LB-agar; $10 \mathrm{~g} / \mathrm{L}$ Tryptone, $5 \mathrm{~g} / \mathrm{L}$ yeast extract, $10 \mathrm{~g} / \mathrm{L} \mathrm{NaCl}, 18 \mathrm{~g} / \mathrm{L}$ Bacto agar, $\mathrm{pH}$ 7.2). Steril paper discs of Whatman filter paper (No. 42) of uniform diameter $(0.6 \mathrm{~cm})$ were used to spot directly different volumes of EO, EO+Ery or Ery, as described in the figure legend. Then, the discs were placed on the overlay of bacteria on LB-agar plate. Growth inhibition halos were observed after overnight incubation at $37^{\circ} \mathrm{C}$. The antibacterial activity was considered if an inhibition halo of growth larger than $0.6 \mathrm{~cm}$ (size of the disk paper) was produced. The antibacterial activity was calculated at least as a mean of three replicates.

The antibacterial activity against the MDR S. aureus strains (11 and 5) was assessed by the broth microdilution method; briefly, bacteria were incubated at $37^{\circ} \mathrm{C}$ in a Luria Bertani (LB) broth $(10 \mathrm{~g} / \mathrm{L}$ tryptone, $10 \mathrm{~g} / \mathrm{L} \mathrm{NaCl}, 5 \mathrm{~g} / \mathrm{L}$ Yeast extract, $\mathrm{pH}$ 7.2). After overnight growth, a 1:100 dilution of the bacterial suspension was incubated at $37^{\circ} \mathrm{C}$ in a microplate containing LB medium and increasing concentrations of $A$. procera $\mathrm{EO}$ (from 0 to $25 \mu \mathrm{g} / \mu \mathrm{L}$ ). Total bacterial concentration was measured at the time of the inoculum and after $18 \mathrm{~h}$ of incubation by reading the optical density at wavelenght of $600 \mathrm{~nm}$ using a microplate reader (GloMax ${ }^{\circledR}$ - Multi Detection System). The experiment was performed in triplicate and the average optical density was calculated. After growth in liquid medium, $100 \mu \mathrm{L}$ of bacterial suspension incubated in presence of different amounts of EO was spread on LB agar plates, 
that were incubated at $37^{\circ} \mathrm{C}$ overnight. After incubation, the colonies were counted to evaluate the viable bacterial count. As a control, bacterial suspension was incubated in the presence of DMSO, solvent in which EO was dissolved.

\subsection{Statistical Analysis}

Results of bioassays are given as means \pm standard error (SE). Statistical analysis was carried out according to Poma et al. [4] by analysis of variance (one-way ANOVA) followed by Tukey's test. Statistica ver. 12 (StatSoft Inc. 1984-2014) was used as software for the analyses.

Author Contributions: Conceptualization, M.N., S.R. and M.S. Methodology, M.L., P.P., P.Z., S.R. and R.A. Validation, M.B., A.V.R., M.N. and M.S. Formal Analysis, P.P., A.V.R. and P.Z. Visualization A.V.R., M.B. Investigation, M.L., P.P., P.Z., S.R. and R.A. Resources, M.N., M.B. and M.S. Data Curation, M.B., S.R., M.N. and M.S. Writing-Original Draft Preparation, R.A., S.R., M.N. and M.S. Writing-Review and Editing, P.P., P.Z., S.R., M.N. and M.S. Supervision, M.N. and M.S. Project Administration, M.N. and M.S. Funding Acquisition, M.N. and M.B.

Funding: This research was supported by grant from MIUR-ITALY PRIN2017 "STOLEN MOLECULES - Stealing natural products from the depot and reselling them as new drug candidates" (Project N. 2017A95NCJ).

Acknowledgments: The authors thank the Director of Palermo Botanic Garden, Rosario Schicchi, for allowing access to the living collections.

Conflicts of Interest: The authors declare no conflict of interest.

\section{References}

1. Sajeva, M.; Costanzo, M. Succulents, the Illustrated Dictionary; Timber Press: Portland, OR, USA, 1994.

2. Crowley, B.E.; Godfrey, L.R. Why all those spines? Anachronistic defences in the Didiereoideae against now extinct lemurs. S. Afr. J. Sci. 2013, 109, 1-7. [CrossRef]

3. Gould, L.; Kelley, E.A.; LaFleur, M. Reproductive female feeding strategies in spiny forest-dwelling Lemur catta in Southern and Southwestern Madagascar: How do females Meet the Challenges of Reproduction in this Harsh Habitat? Folia Primatol. 2015, 86, 16-24. [CrossRef] [PubMed]

4. Droscher, I.; Rothman, J.M.; Ganzhorn, J.U.; Kappeler, P.M. Nutritional consequences of folivory in a small-bodied lemur (Lepilemur Leucopus): Effects of season and reproduction on nutrient balancing. Am. J. Phys. Anthropol. 2016, 160, 197-207. [CrossRef] [PubMed]

5. Génin, F. Who sleeps with whom? Sleeping association and socio-territoriality in Microcebus griseorufus. J. Mammal. 2010, 91, 942-951. [CrossRef]

6. Gardner, C.; Ferguson, B.; Rebara, F.; Ratsifandrihamanana, N. Integrating traditional values and management regimes into Madagascar's expanded protected area system: The case of Ankodida. In Protected Landscapes and Cultural and Spiritual Values; Mallarach, J.M., Ed.; Volume 2 in the Series Values of Protected Landscapes and Seascapes, IUCN, GTZ and Obra Social de Caixa Catalunya; Kasparek Verlag: Heidelberg, Germany, 2008; pp. 92-103. ISBN 978-3-925064-60-9.

7. Yoshioka, Y.; Ohshima, H.; Maeda, Y. Effects of Soil Chemical Properties on Vegetation of Alluaudia procera Drake, a Species Endemic to Madagascar. J. Agric. Sci. Tokyo Univ. Agric. 2013, 58, 117-124.

8. Tengö, M.; von Heland, J. Trees and Tree-Planting in Southern Madagascar: Sacredness and Remembrance. In Greening in the Red Zone: Disaster, Resilience and Community Greening; Tidball, K.G., Krasny, M.E., Eds.; Springer Science + Business Media: Dordrecht, The Netherlands, 2014; pp. 334-337. [CrossRef]

9. Linholm, P.; Gullbo, J.; Claeson, P.; Goeransson, U.; Johansson, S.; Backlund, A.; Larsson, R.; Bohlin, L. Selective cytotoxicity evaluation in anticancer drug screening of fractionated plant extracts. J. Biomol. Screen. 2002, 7, 333-340. [CrossRef]

10. Rasamoelisendra, R.; Voirin, B.; Favre-Bonvin, J.; Andriantsiferana, M.; Rabesa, Z. 6-C-Methyl-and 6, 8-di-C-methyl-3, 7-di-O-methylkaempferol from Alluaudia dumosa. Phytochemistry 1989, 28, 1996-1997. [CrossRef]

11. Poma, P.; Labbozzetta, M.; Notarbartolo, M.; Bruno, M.; Maggio, A.; Rosselli, S.; Sajeva, M.; Zito, P. Chemical composition, in vitro antitumor and pro-oxidant activities of Glandora rosmarinifolia (Boraginaceae) essential oil. PLoS ONE 2018, 13, e0196947. [CrossRef] 
12. Bakkali, F.; Averbeck, S.; Averbeck, D.; Idaomar, M. Biological effects of essential oils-A review. Food Chem. Toxicol. 2008, 46, 446-475. [CrossRef]

13. Dudareva, N.; Negre, F.; Dinesh, A.; Nagegowda, D.A.; Orlova, I. Plant volatiles: Recent advances and future perspectives. Crit. Rev. Plant Sci. 2006, 25, 417-440. [CrossRef]

14. Zito, P.; Labbozzetta, M.; Notarbartolo, M.; Sajeva, M.; Poma, P. Essential oil of Cyphostemma juttae (Vitaceae): Chemical composition and antitumor mechanism in triple negative breast cancer cells. PLOS ONE 2019, 14, e0214594. [CrossRef]

15. Notarbartolo, M.; Cervello, M.; Dusonchet, L.; Cusimano, A.; D'Alessandro, N. Resistance to diverse apoptotic triggers in multidrug resistant HL60 cells and its possible relationship to the expression of P-glycoprotein, Fas and of the novel anti-apoptosis factors IAP (inhibitory of apoptosis proteins). Cancer Lett. 2002, 180, 91-101. [CrossRef]

16. Marcelletti, J.F.; Sikic, B.I.; Cripe, L.D.; Paietta, E. Evidence of a role for functional heterogeneity in multidrug resistance transporters in clinical trials of P-glycoprotein modulation in acute myeloid leukemia. Cytom. $B$ Clin. Cytom. 2019, 96, 57-66. [CrossRef]

17. Liu, B.; Li, L.J.; Gong, X.; Zhang, W.; Zhang, H.; Zhao, L. Co-expression of ATP binding cassette transporters is associated with poor prognosis in acute myeloid leukemia. Oncol. Lett. 2018, 15, 6671-6677. [CrossRef]

18. D'Andrea, A.; Martinez, Y.Z.; Alduina, R.; Monteverde, V.; Molina, C.F.; Vitale, M. Comparison of two PCR methods for detection of Leptospira interrogans in formalin-fixed and paraffin-embedded tissues. Mem. Inst. Oswaldo Cruz 2012, 107, 85-88. [CrossRef]

19. Vitale, M.; Scatassa, M.L.; Cardamone, C.; Oliveri, G.; Piraino, C.; Alduina, R.; Napoli, C. Staphylococcal food poisoning case and molecular analysis of toxin genes in Staphylococcus aureus strains isolated from food in Sicily, Italy. Foodborne Pathog. Dis. 2015, 12, 21-23. [CrossRef]

20. Dresler, C.; Saladino, M.L.; Demirbag, C.; Caponetti, E.; Chillura Martino, D.F.; Alduina, R. Development of controlled release systems of biocides for the conservation of cultural heritage. Int. Biodeterior. Biodegrad. 2017, 125, 150-156. [CrossRef]

21. Mulani, M.S.; Kamble, E.E.; Kumkar, S.N.; Tawre, M.S.; Pardesi, K.R. Emerging strategies to combat eskape pathogens in the era of antimicrobial resistance: A review. Front. Microbiol. 2019, 10, 539. [CrossRef]

22. Mandal, S.M.; Ghosh, A.K.; Roy, A.; Hazra, T.; Franco, O.L. Challenges and future prospects of antibiotic therapy: From peptides to phages utilization. Front. Pharmacol. 2014, 5, 105. [CrossRef]

23. Linstrom, P.J.; Mallard, W.G. NIST Chemistry WebBook, NIST Standard Reference Database Number 69; National Institute of Standards and Technology: Gaithersburg, MD, USA, 2000; (last update 2018). Available online: https://webbook.nist.gov/chemistry/ (accessed on 18 June 2019).

24. Zito, P.; Sajeva, M.; Bruno, M.; Rosselli, S.; Maggio, A.; Senatore, F. Essential oils composition of Periploca laevigata Aiton subsp. angustifolia (Labill.) Markgraf (Apocynaceae-Periplocoideae). Nat. Prod. Res. 2013, 27, 255-265. [CrossRef]

25. Leffingwell, J.C.; Alford, E.D.; Leffingwell, D.; Penn, R. Identification of the volatile constituents of Cyprian Latakia tobacco by dynamic and static headspace analyses. Leffingwell Rep. 2013, 5, 1-29.

26. Arokiyaraj, S.; Choi, S.H.; Lee, Y.; Bharanidharan, R.; Hairul-Islam, V.I.; Vijayakumar, B.; Oh, Y.K.; Dinesh-Kumar, V.; Vincent, S.; Kim, K.H. Characterization of ambrette seed oil and its mode of action in bacteria. Molecules 2015, 20, 384-395. [CrossRef]

27. Witkowska-Banaszczak, E. Flavonoids from Trollius europaeus flowers and evaluation of their biological activity. J. Pharm. Pharmacol. 2018, 70, 550-558. [CrossRef]

28. Hirose, S.; Joichi, A.; Nakamura, S.; Awano, K. Volatile components of musky scent of orchids. Flavour Fragr. J. 1999, 14, 183-184. [CrossRef]

29. Dung, N.X.; Van Khiên, P.; Nhuân, D.D.; Hoi, T.M.; Ban, N.K.; Leclercq, P.A.; Muselli, A.; Bighelli, A.; Casanova, J. Composition of the seed oil of Hibiscus abelmoschus L. (Malvaceae) growing in Vietnam. J. Essent. Oil Res. 1999, 11, 447-452. [CrossRef]

30. Nee, T.Y.; Cartt, S.; Pollard, M.R. Seed coat components of Hibiscus abelmoschus. Phytochemistry 1986, 25, 2157-2161. [CrossRef]

31. Brunton, L.; Dandan, R.H.; Knollmann, B.C. Goodman and Gilman's The Pharmacological Basis of Therapeutics, 13th ed.; McGraw-Hill: New York, NY, USA, 1996.

32. Moes, D.J.; Guchelaar, H.J.; de Fijter, J.W. Sirolimus and everolimus in kidney transplantation. Drug Discov. Today 2015, 20, 1243-1249. [CrossRef] 
33. Nayman, A.H.; Siginc, H.; Zemheri, E.; Yencilek, F.; Yildirim, A.; Telci, D. Dual-Inhibition of mTOR and Bcl-2 enhances the anti-tumor effect of everolimus against renal cell carcinoma in vitro and in vivo. J. Cancer 2019, 10, 1466-1478. [CrossRef]

34. Hamieh, L.; Choueiri, T.K.; Ogórek, B.; Khabibullin, D.; Rosebrock, D.; Livitz, D.; Fay, A.; Pignon, J.C.; McDermott, D.F.; Agarwal, N.; et al. Mechanisms of acquired resistance to rapalogs in metastatic renal cell carcinoma. PLoS Genet. 2018, 14, e1007679. [CrossRef]

35. Notarbartolo, M.; Cervello, M.; Poma, P.; Dusonchet, L.; Meli, M.; D'Alessandro, N. Expression of the IAPs in multidrug resistant tumor cells. Oncol. Rep. 2004, 11, 133-136. [CrossRef]

36. Notarbartolo, M.; Cervello, M.; Dusonchet, L.; D'Alessandro, N. NAIP-deltaEx10-11: A novel splice variant of the apoptosis inhibitor NAIP differently expressed in drug-sensitive and multidrug-resistant HL60 leukemia cells. Leuk. Res. 2002, 26, 857-862. [CrossRef]

37. Tamm, I.; Kornblau, S.M.; Segall, H.; Krajewski, S.; Welsh, K.; Kitada, S.; Scudiero, D.A.; Tudor, G.; Qui, Y.H.; Monks, A.; et al. Expression and prognostic significance of IAP-family genes in human cancers and myeloid leukemias. Clin. Cancer Res. 2000, 6, 1796-1803.

38. Stone, A.; Zukerman, T.; Flaishon, L.; Yakar, R.B.; Rowe, J.M. Efficacy outcomes in the treatment of older or medically unfit patients with acute myeloid leukaemia: A systematic review and meta-analysis. Leuk. Res. 2019, 82, 36-42. [CrossRef]

39. Rubino, S.; Busà, R.; Attanzio, A.; Alduina, R.; Di Stefano, V.; Girasolo, M.A.; Orecchio, S.; Tesoriere, L. Synthesis, properties, antitumor and antibacterial activity of new $\mathrm{Pt}(\mathrm{II})$ and $\mathrm{Pd}(\mathrm{II})$ complexes with 2,2'-dithiobis(benzothiazole) ligand. Bioorg. Med. Chem. 2017, 25, 2378-2386. [CrossRef]

40. Rubino, S.; Pibiri, I.; Minacori, C.; Alduina, R.; Di Stefano, V.; Orecchio, S.; Buscemi, S.; Girasolo, M.A.; Tesoriere, L.; Attanzio, A. Synthesis, structural characterization, anti-proliferative and antimicrobial activity of binuclear and mononuclear Pt(II) complexes with perfluoroalkyl-heterocyclic ligands. Inorg. Chim. Acta 2018, 483, 180-190. [CrossRef]

41. Ciabocco, M.; Cancemi, P.; Saladino, M.L.; Caponetti, E.; Alduina, R.; Berrettoni, M. Synthesis and antibacterial activity of iron-hexacyanocobaltate nanoparticles. J. Biol. Inorg. Chem. 2018, 23, 385-398. [CrossRef]

42. Vitale, M.; Galluzzo, P.; Buffa, P.G.; Carlino, E.; Spezia, O.; Alduina, R. Comparison of antibiotic resistance profile and biofilm production of Staphylococcus aureus isolates derived from human specimens and animal-derived samples. Antibiotics 2019, 8, 97. [CrossRef]

43. Vitale, M.; Gaglio, S.; Galluzzo, P.; Cascone, G.; Piraino, C.; Di Marco Lo Presti, V.; Alduina, R. Antibiotic resistance profiling, analysis of virulence aspects and molecular genotyping of Staphylococcus aureus isolated in Sicily, Italy. Foodborne Pathog. Dis. 2018, 15, 177-185. [CrossRef]

44. Rauh, W. Succulent and Xerophytic Plants of Madagascar; Strawberry Press: Mill Valley, CA, USA, 1995; Volume I.

45. Rauh, W. Succulent and Xerophytic Plants of Madagascar; Strawberry Press: Mill Valley, CA, USA, 1998; Volume II.

46. World Conservation Monitoring Centre. Alluaudia procera. The IUCN Red List of Threatened Species 1998: e.T30436A9550092. Available online: https://www.iucnredlist.org/species/30436/124141236 (accessed on 17 April 2019).

47. Zito, P.; Sajeva, M.; Bruno, M.; Maggio, A.; Rosselli, S.; Senatore, F.; Formisano, C. Essential oil composition of the fruits of Periploca laevigata Aiton subsp. angustifolia (Labill.) Markgraf (Apocynaceae-Periplocoideae). Nat. Prod. Res. 2011, 25, 1339-1346. [CrossRef]

48. Adams, R.P. Identification of Essential Oil Components by Gas Chromatography/Mass Spectroscopy, 4th ed.; Allured Publishing: Carol Stream, IL, USA, 2007.

49. Giardina, A.; Alduina, R.; Gottardi, E.; Di Caro, V.; Süssmuth, R.D.; Puglia, A.M. Differential proteomic analysis highlights metabolic strategies associated with balhimycin production in Amycolatopsis balhimycina chemostat cultivations. Microb. Cell Fact. 2010, 9, 44-54. [CrossRef]

50. Lo Grasso Maffioli, S.; Sosio, M.; Bibb, M.; Puglia, A.M.; Alduina, R. Two master switch regulators trigger A40926 biosynthesis in Nonomuraea sp. strain ATCC 39727. J. Bacteriol. 2015, 197, 2536-2544. [CrossRef]

(C) 2019 by the authors. Licensee MDPI, Basel, Switzerland. This article is an open access article distributed under the terms and conditions of the Creative Commons Attribution (CC BY) license (http://creativecommons.org/licenses/by/4.0/). 